\title{
ERRATA
}

Horm. metabol. Res. 19 (1987) 497-501

○ Georg Thieme Verlag Stuttgart - New York

\section{Androgen Binding in Cultured Human Fibroblasts from Patients with Idiopathic Hypospadias}

\author{
H.-U. Schweikert ${ }^{* 1}$, W. Knauf ${ }^{1}$, Gabriela Romalo' ${ }^{1}$ W. Höller ${ }^{2}$, F. Bidlingmaier ${ }^{1}$ and D. Knorr ${ }^{2}$ \\ ${ }_{2}^{1}$ Medizinische Universitäts-Poliklinik and Institut für Klinische Biochemie, Universität Bonn, and \\ 2 Universitäts-Kinderklinik, Universität München, München, Germany
}

The last paragraph of the legend of Figure 2 on page 499 should read as follows:

Testicular feminization ( $(0)$, Rejfenstein syndrome (o), perineoscrotal pseudovaginal hypospadias

$(5 \alpha$-reductase deficiency) $(\nabla)$.

On page 501 the two following references were inadvertently omitted:

Schweikert, H.U., L. Milewich, J.D. Wilson: Aromatization of androstenedione to estrone by cultured human fibroblasts. J. Clin. Endocrinol. Metab. 43: 785-795 (1975)
Schweikert, H.U.: Conversion of androstenedione to estrone in human fibroblasts, cultured from prostate, genital and nongenital skin. Horm. Metab. Res. 11: 635-640 (1979) 